\title{
Perilaku pemeliharaan kebersihan gigi tiruan lepasan pada masyarakat Desa Kema II Kecamatan Kema
}

\author{
${ }^{1}$ Inda P. Kaliey \\ ${ }^{2}$ Vonny N. S. Wowor \\ ${ }^{3}$ Benedictus S. Lampus
}

\author{
${ }^{1}$ Kandidat Skripsi Program Studi Pendidikan Dokter Gigi Fakultas Kedokteran \\ ${ }^{2}$ Program Studi Pendidikan Dokter Gigi Fakultas Kedokteran \\ ${ }^{3}$ Bagian Kesehatan Masyarakat Fakultas Kedokteran \\ Universitas Sam Ratulangi Manado \\ Email: indakaliey08@gmail.com
}

\begin{abstract}
Abstarct: The main purpose of using denture is to restore the aesthetic function, speech function, and masticatory function which are disturbed due to tooth loss. Unclean oral condition can cause the oral cavity become susceptible to caries and periodontal disease. Poor behavior to maintain dental and oral hygiene of removable denture users plays an important role in the occurrence of these two diseases. Removable denture that is kept unclean is harmful to the hard tissue as well as the soft tissue of the oral cavity. This study aimed to determine the behavior of removable denture maintenance among Kema II villagers in Kema. This was a descriptive study with a cross sectional design. There were 62 respondents as samples. The results of the behavior score of denture hygiene maintenance were as follows: score of knowledge was 552; score of attitude was 581; and score of action was 572. Conclusion: The behavior to maintain the removable denture hygiene of Kema II villagers which included knowledge, attitude, and action was classified as poor category.
\end{abstract}

Keywords: behavior, maintenance of hygiene dentures, removable denture

\begin{abstract}
Abstrak: Tujuan utama penggunaan gigi tiruan yaitu untuk memulihkan fungsi estetik, fungsi bicara, serta fungsi pengunyahan yang terganggu akibat kehilangan gigi. Kondisi rongga mulut yang kurang terjaga kebersihannya dapat menyebabkan rongga mulut rentan terhadap karies dan penyakit periodontal. Perilaku pemeliharaan kebersihan gigi dan mulut yang kurang baik dari pengguna gigi tiruan lepasan berperan penting pada terjadinya kedua penyakit tersebut. Gigi tiruan lepasan yang kurang terjaga kebersihannya bukan saja menimbulkan gangguan pada jaringan keras gigi namun juga pada jaringan lunak mulut. Penelitian ini bertujuan untuk mengetahui perilaku pemeliharaan kebersihan gigi tiruan lepasan pada masyarakat Desa Kema II Kecamatan Kema. Jenis penelitian ialah deskriptif dengan desain potong lintang. Sampel berjumlah 62 responden. Hasil penelitian menunjukkan skor pengukuran perilaku pemeliharaan kebersihan gigi tiruan yang terdiri dari skor pengetahuan sebesar 552; skor sikap sebesar 581; dan skor tindakan sebesar 572. Simpulan: Perilaku pemeliharaan kebersihan gigi tiruan lepasan masyarakat Desa Kema II Kecamatan Kema yang meliputi pengetahuan, sikap dan tindakan kesemuanya tergolong kurang baik.
\end{abstract}

Kata kunci: perilaku, pemeliharaan kebersihan gigi tiruan, gigi tiruan lepasan

Gigi merupakan salah satu organ tubuh penting dalam mulut yang digunakan untuk mengunyah makanan, memroduksi bunyi atau suara saat bicara serta memiliki fungsi estetik bagi individu. ${ }^{1}$ Oleh berbagai sebab gigi tidak selamanya berada dalam rongga 
mulut, namun bisa terlepas atau tercabut dari tempatnya di tulang rahang. Faktorfaktor yang menyebabkan terjadinya kehilangan gigi, antara lain penyakit periodontal dan penyakit karies gigi. Agar tidak menimbulkan dampak yang tidak diinginkan, maka ketika terjadi kehilangan gigi perlu dibuatkan penggantinya berupa gigi tiruan. ${ }^{2}$ Gigi tiruan merupakan piranti yang dibuat untuk menggantikan gigi dan jaringan lunak disekitarnya yang hilang. Pemakaian gigi tiruan akan mengembalikan fungsi estetik, pengunyahan, fungsi bicara, serta memelihara dan mempertahankan kesehatan jaringan sekitarnya. ${ }^{3}$ Berbagai jenis gigi tiruan menjadi pilihan bagi individu yang mengalami kehilangan gigi. Secara umum gigi tiruan terdiri dari gigi tiruan cekat dan gigi tiruan lepasan. Gigi tiruan cekat, dipasang secara permanen dan tidak dapat dilepas-lepas sendiri oleh penggunanya, sedangkan gigi tiruan lepasan dapat dilepas dan dipasangkan sendiri oleh penggunanya. Gigi tiruan lepasan lebih banyak dipilih masyarakat oleh karena relatif lebih murah biaya pembuatannya dibandingkan gigi tiruan cekat. $^{4}$

Hasil Riset Kesehatan Dasar (RISKESDAS) 2007 menunjukkan persentase pengguna gigi tiruan di

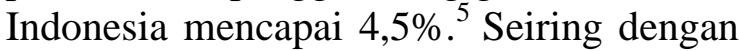
bertambahnya usia, risiko kehilangan gigi menjadi semakin besar, sehingga kebutuhan akan pemakaian gigi tiruan pun menjadi semakin meningkat. Pemakaian gigi tiruan memiliki tujuan untuk mencegah terjadinya gangguan fungsi akibat kehilangan gigi, tetapi seringkali terjadi masyarakat kurang menyadari pentingnya pemeliharaan kebersihan gigi tiruan yang digunakan. Kebersihan gigi tiruan yang kurang terjaga dapat memberi dampak bagi kesehatan rongga mulut pengguna gigi tiruan. ${ }^{1,6}$

Menurut Basker et al. pemakaian gigi tiruan lepasan secara terus menerus dan tidak bersih dapat meningkatkan akumulasi plak. ${ }^{7}$ Pemakaian gigi tiruan menyebabkan mukosa di bawah gigi tiruan akan tertutup dalam jangka waktu yang lama, sehingga menghalangi pembersihan permukaan mukosa maupun gigi tiruan oleh lidah dan saliva. $^{6}$ Berdasarkan survei yang telah dilakukan di Turki pada tahun 2005 tentang sikap dokter gigi terhadap kebersihan gigi tiruan, diketahui bahwa banyak masyarakat yang sudah mendapat instruksi tentang cara pemeliharaan gigi tiruan, tetapi tidak peduli akan kebersihan gigi tiruan dan rongga mulutnya. ${ }^{8}$ Pemeliharaan kebersihan gigi tiruan erat kaitannya dengan perilaku penggunanya.

Perilaku pengguna gigi tiruan sehubungan dengan pemakaian gigi tiruan berperan penting pada kesehatan rongga mulutnya. Gigi asli yang masih tinggal serta jaringan pendukung harus tetap dijaga kesehatannya setelah pemakaian gigi tiruan. Kebersihan gigi dan mulut yang kurang terjaga termasuk kebersihan gigi tiruan yang digunakan dapat menyebabkan gangguan pada mukosa pendukung gigi tiruan. Salah satu gangguan berupa peradangan yang dikenal sebagai denture stomatitis. Pengetahuan yang dimiliki pengguna gigi tiruan berkaitan dengan pemeliharaan kebersihan merupakan faktor penting yang membentuk sikap dan tindakan individu dalam keberhasilan penggunaan gigi tiruan. ${ }^{9}$

Desa Kema II terletak di kecamatan Kema Kabupaten Minahasa Utara dengan populasi penduduk 2736 jiwa. Pada survei awal yang dilakukan oleh peneliti, terdapat cukup banyak pengguna gigi tiruan lepasan di Desa Kema II. Berdasarkan wawancara yang dilakukan dengan beberapa pengguna gigi tiruan lepasan sehubungan pemakaiaan dan pemeliharaan gigi tiruan, diperoleh informasi setelah pemakaian gigi tiruan ada pengguna yang tidak pernah melepas gigi tiruan yang digunakan. Alasan yang dikemukakan karena takut gigi tiruan menjadi longgar. Pengguna lainnya tetap menggunakan gigi tiruan saat tidur malam. Informasi lainnya yang diperoleh berupa keluhan pengguna gigi tiruan berkaitan dengan banyaknya lubang pada gigi setelah pemakaiaan gigi tiruan.

Berdasarkan latar belakang yang dikemukan di atas, peneliti merasa tertarik 
untuk meneliti tentang perilaku pemeliharaan kebersihan gigi tiruan lepasan pada masyarakat Desa Kema II Kecamatan Kema. Desa ini dipilih sebagai lokasi penelitian karena penelitian serupa belum pernah dilakukan di desa ini. Di samping itu peneliti memiliki kemudahan akses untuk mendapatkan data karena merupakan desa asal peneliti.

\section{BAHAN DAN METODE PENELITIAN}

Jenis penelitian ini ialah deskriptif dengan desain potong lintang. Jumlah responden yang diteliti yaitu 62 orang diperoleh dengan menggunakan metode total sampling.

Perilaku pemeliharaan kebersihan gigi tiruan lepasan diukur menggunakan 21 pertanyaan yang terdiri dari 7 pertanyaan pengetahuan, 7 pertanyaan sikap dan 7 pertanyaan tindakan. Setiap pertanyaan diberi skor 2 untuk jawaban tahu, setuju dan ya, kemudian skor 1 untuk jawaban tidak tahu, tidak setuju, dan tidak. Jumlah skor tertinggi yaitu $2 \times 7 \times 62=868$; dan jumlah skor terendah ialah $1 \times 7 \times 62=434$

Data hasil pengukuran secara kontinum dapat dilihat seperti di bawah ini:

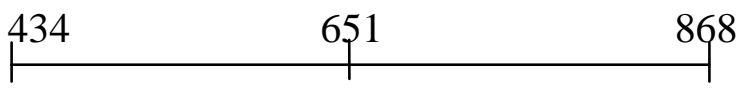

Kurang baik

Baik

\section{HASIL PENELITIAN}

Karakteristik respoden dalam penelitian ini berdasarkan jenis kelamin, usia, pendidikan, pekerjaan, jenis gigi tiruan lepasan (GTL) dan tempat pembuatan GTL dapat dilihat pada Tabel 1-7.

Tabel 1. Karakteristik responden penelitian berdasarkan jenis kelamin

\begin{tabular}{ccc}
\hline Jenis kelamin & $\begin{array}{c}\text { Jumlah } \\
\text { responden }\end{array}$ & $\mathbf{( \% )}$ \\
\hline Laki-laki & 23 & 37,1 \\
\hline Perempuan & 39 & 62,9 \\
Jumlah & 62 & 100 \\
\hline
\end{tabular}

Tabel 2. Karakteristik responden penelitian berdasarkan usia

\begin{tabular}{ccc}
\hline $\begin{array}{c}\text { Usia } \\
\text { (tahun) }\end{array}$ & $\begin{array}{c}\text { Jumlah } \\
\text { responden }\end{array}$ & $\mathbf{( \% )}$ \\
\hline$<30$ & 3 & 4,8 \\
$31-40$ & 6 & 9,6 \\
$41-50$ & 17 & 27,4 \\
$51-60$ & 16 & 26 \\
$>61$ & 20 & 32,2 \\
Total & 62 & $100 \%$ \\
\hline
\end{tabular}

Tabel 3. Karakteristik responden penelitian berdasarkan pendidikan terakhir

\begin{tabular}{ccc}
\hline $\begin{array}{c}\text { Pendidikan } \\
\text { terakhir }\end{array}$ & $\begin{array}{c}\text { Jumlah } \\
\text { responden }\end{array}$ & $\mathbf{( \% )}$ \\
\hline SD & 8 & 13 \\
SMP & 12 & 19,3 \\
SMA & 40 & 64,5 \\
Perguruan Tinggi & 2 & 3,2 \\
Total & 62 & $100 \%$ \\
\hline
\end{tabular}

Tabel 4. Karakteristik responden penelitian berdasarkan lama penggunaan gigi tiruan

\begin{tabular}{lcc}
\hline $\begin{array}{c}\text { Lama } \\
\text { penggunaan }\end{array}$ & $\begin{array}{c}\text { Jumlah } \\
\text { responden }\end{array}$ & $\mathbf{( \% )}$ \\
\hline$<1$ tahun & 19 & 30,7 \\
2-6tahun & 23 & 37 \\
$7-11$ tahun & 11 & 17,8 \\
$>12$ tahun & 9 & 14,5 \\
\hline \multicolumn{1}{c}{ Total } & 62 & $100 \%$ \\
\hline
\end{tabular}

Tabel 5. Karakteristik responden penelitian berdasarkan pekerjaan

\begin{tabular}{ccc}
\hline Pekerjaan & $\begin{array}{c}\text { Jumlah } \\
\text { responden }\end{array}$ & $\mathbf{( \% )}$ \\
\hline Tidak bekerja & 32 & 51,6 \\
Wiraswasta & 14 & 22,5 \\
PNS & 4 & 6,5 \\
Pensiunan & 4 & 6,5 \\
Nelayan & 3 & 4.8 \\
Tukang ojek & 4 & 6,5 \\
Supir & 1 & 1,6 \\
Total & 62 & $100 \%$ \\
\hline
\end{tabular}

Tabel 6. Karakteristik responden penelitian berdasarkan jenis gigi tiruan lepasan

\begin{tabular}{ccc}
\hline Jenis GTL & Jumlah & $(\boldsymbol{\%})$ \\
\hline GTSL & 60 & 96,8 \\
GTP & 2 & 3,2 \\
Total & 62 & $100 \%$ \\
\hline
\end{tabular}


Tabel 7. Karakteristik responden penelitian berdasarkan tempat pembuatan GTL

\begin{tabular}{ccc}
\hline $\begin{array}{c}\text { Tempat } \\
\text { pembuatan GTL }\end{array}$ & Jumlah & $\mathbf{( \% )}$ \\
\hline Tukang gigi & 55 & 88,7 \\
Dokter gigi & 7 & 11,3 \\
\hline Total & 62 & $100 \%$ \\
\hline
\end{tabular}

Perilaku pemeliharaan kebersihan GTL pada masyarakat Desa Kema II

Bedasarkan hasil perhitungan

keseluruhan pada Tabel 8, maka pengetahuan masyarakat pengguna GTL di Desa Kema II memperoleh skor 552 dan termasuk pada kategori kurang baik (Gambar 1).

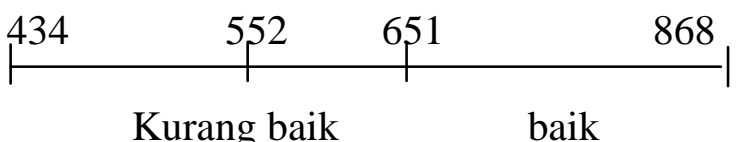

Gambar 1. Kategori penilaian pengetahuan masyarakat tentang pemeliharaan kebersihan GTL

Berdasarkan hasil perhitungan keseluruhan pada Tabel 9, maka sikap pengguna GTL di Desa Kema II memperoleh skor 581 dan termasuk pada kategori kurang baik (Gambar 2).

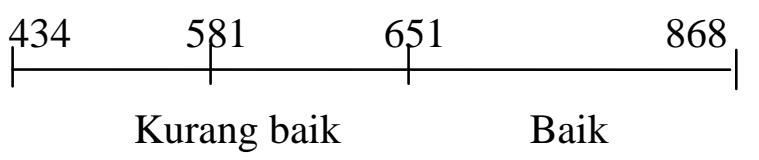

Gambar 2. Kategori penilaian sikap masyarakat tentang pemeliharaan kebersihan GTL

Berdasarkan hasil perhitungan keseluruhan pada Tabel 10, maka tindakan pengguna GTL di Desa Kema II memperoleh skor 572 dan termasuk pada kategori kurang baik (Gambar 3).

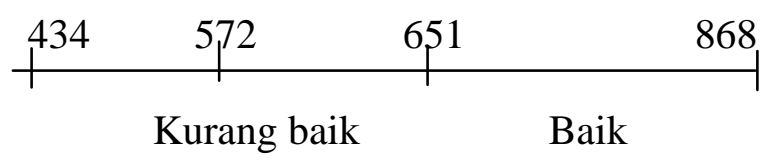

Gambar 3. Kategori penilaian tindakan masyarakat tentang pemeliharaan kebersihan GTL

\section{BAHASAN}

Pengetahuan merupakan salah satu faktor yang berperan dalam proses perkembangan kesehatan seseorang. Semakin banyak pengetahuan seseorang terhadap kesehatan gigi dan mulut, maka semakin baik pula tingkat kesehatan yang dimiliki seseorang. Berdasarkan hasil penelitian didapat bahwa perolehan skor pengetahuan masyarakat tentang pemeliharaan kebersihan gigi tiruan lepasan sebesar 552 yang menunjukkan bahwa pengetahuan masyarakat tergolong kurang baik.

Faktor-faktor yang memengaruhi pengetahuan antara lain meliputi usia, pendidikan, sosial ekonomi. Pada penelitian ini sebagian besar responden $(32,2 \%)$ berusia >61 tahun (tergolong kategori lansia). Pada lansia umumnya terjadi penurunan dari segi fisik termasuk juga daya ingat. Kepikunan yang berat (demensia) akan berpengaruh pada pengetahuan yang dimiliki. Hal ini didukung oleh penelitian Liana et $\mathrm{al}^{6}$ bahwa $61 \%$ lansia dengan usia $>65$ tahun memiliki pengetahuan yang kurang baik. Di samping itu penurunan keadaan fisik juga memengaruhi kemampuan untuk mengurus diri sendiri, termasuk dalam pemeliharaan gigi tiruan. Menurut penelitian Barreiro et al. lansia kurang memiliki pengetahuan dan kemampuan yang cukup untuk memelihara kebersihan rongga mulut dan gigi tiruannya. ${ }^{10,11}$

Berdasarkan hasil penelitian ini, terlihat sebagian besar responden $(64,5 \%)$ memiliki tingkat pendidikan terakhir SMA, yang dapat dikatakan sudah memiliki pengetahuan cukup secara umum, namun pengetahuan yang lebih spesifik berkaitan dengan pemeliharaan kebersihan gigi tiruan umumnya masih kurang. Pengguna gigi tiruan bisa memiliki pengetahuan yang baik tentang pemeliharaan gigi tiruan yang digunakan bila sebelumnya mendapatkan informasi dari yang melakukan perawatan pembuatan gigi tiruan, yakni dokter gigi atau mendapatkan informasi/pengetahuan dari sumber lainnya seperti penyuluhan dari tenaga kesehatan gigi atau media informasi lainnya. 
Tabel 8. Distribusi responden berdasarkan pengetahuan tentang pemeliharaan kebersihan gigi tiruan lepasan

\begin{tabular}{|c|c|c|c|c|}
\hline No & Pertanyaan & Tahu & $\begin{array}{l}\text { Tidak } \\
\text { tahu }\end{array}$ & $\begin{array}{l}\text { Total skor } \\
\text { penelitian }\end{array}$ \\
\hline 1. & $\begin{array}{l}\text { Tahukah saudara/saudari bahwa pemakaian gigi tiruan } \\
\text { dapat berdampak buruk pada kebersihan rongga mulut? }\end{array}$ & 9 & 53 & 71 \\
\hline 2. & $\begin{array}{l}\text { Tahukah saudara/saudari bahwa pada permukaan gigi } \\
\text { tiruan yang kurang terjaga kebersihannya, jamur dan } \\
\text { bakteri bisa tumbuh dan berkembang? }\end{array}$ & 8 & 54 & 70 \\
\hline 3. & $\begin{array}{l}\text { Tahukah saudara/saudari bahwa gigi tiruan yang } \\
\text { kurang terjaga kebersihannya dapat menimbulkan } \\
\text { gangguan pada kesehatan gigi dan mulut? }\end{array}$ & 4 & 58 & 66 \\
\hline 4. & $\begin{array}{l}\text { Tahukah saudara/saudari gigi tiruan harus dibersihkan } \\
\text { setiap selesai makan? }\end{array}$ & 18 & 44 & 80 \\
\hline 5. & $\begin{array}{l}\text { Tahukah saudara/saudari gigi tiruan yang digunakan } \\
\text { dibersihkan dengan cara disikat dan menggunakan } \\
\text { sabun/detergen untuk menghilangkan sisa makanan } \\
\text { dan bakteri serta jamur yang menempel pada } \\
\text { permukaannya? }\end{array}$ & 62 & 0 & 124 \\
\hline 6. & $\begin{array}{l}\text { Tahukah saudara/saudari gigi tiruan yang sudah } \\
\text { dibersihkan dengan sikat dan sabun/detergen sebaiknya } \\
\text { direndam dalam larutan pembersih gigi tiruan? }\end{array}$ & 3 & 59 & 65 \\
\hline 7. & $\begin{array}{l}\text { Tahukah saudara/saudari gigi tiruan harus dilepas pada } \\
\text { malam hari saat akan tidur dan direndam dalam air } \\
\text { bersih? }\end{array}$ & 14 & 48 & 76 \\
\hline & Total skor & & & 552 \\
\hline
\end{tabular}

Tabel 9. Distribusi responden berdasarkan sikap tentang pemeliharan kebersihan gigi tiruan lepasan

\begin{tabular}{|c|c|c|c|c|}
\hline No & Pertanyaan & Setuju & $\begin{array}{l}\text { Tidak } \\
\text { setuju }\end{array}$ & $\begin{array}{l}\text { Total skor } \\
\text { penelitian }\end{array}$ \\
\hline 1. & $\begin{array}{l}\text { Setujukah saudara/saudari pada pendapat bahwa } \\
\text { pemakaian gigi tiruan dapat berdampak buruk pada } \\
\text { kebersihan rongga mulut? }\end{array}$ & 19 & 43 & 81 \\
\hline 2. & $\begin{array}{l}\text { Setujukah saudara/saudari pada pendapat bahwa } \\
\text { gigi tiruan yang kurang terjaga kebersihannya dapat } \\
\text { menimbulkan gangguan pada kesehatan gigi dan } \\
\text { mulut? }\end{array}$ & 14 & 48 & 76 \\
\hline 3. & $\begin{array}{l}\text { Setujukah saudara/saudari pada pendapat bahwa } \\
\text { pada permukaan gigi tiruan yang kurang terjaga } \\
\text { kebersihannya, jamur dan bakteri bisa tumbuh dan } \\
\text { berkembang? }\end{array}$ & 15 & 47 & 77 \\
\hline 4. & $\begin{array}{l}\text { Setujukah saudara/saudari pada pendapat bahwa } \\
\text { gigi tiruan harus dibersihkan setiap selesai makan? }\end{array}$ & 20 & 42 & 82 \\
\hline 5. & $\begin{array}{l}\text { Setujukah saudara/saudari pada pendapat gigi tiruan } \\
\text { yang digunakan dibersihkan dengan cara disikat dan } \\
\text { menggunakan sabun/detergen untuk menghilangkan } \\
\text { sisa makanan dan bakteri serta jamur yang } \\
\text { menempel pada permukaannya? }\end{array}$ & 62 & 0 & 124 \\
\hline 6. & $\begin{array}{l}\text { Setujukah saudara/saudari pada pendapat bahwa } \\
\text { gigi tiruan yang sudah dibersihkan dengan sikat dan } \\
\text { sabun/detergen sebaiknya direndam dalam larutan } \\
\text { pembersih gigi tiruan? }\end{array}$ & 1 & 61 & 63 \\
\hline 7. & $\begin{array}{l}\text { Setujukah saudara/saudari pada pendapat bahwa } \\
\text { gigi tiruan harus dilepas pada malam hari dan } \\
\text { direndam dalam larutan air bersih? }\end{array}$ & 16 & 46 & 78 \\
\hline & Total skor & & & 581 \\
\hline
\end{tabular}


Kaliey, Wowor, Lampus: Perilaku pemeliharaan kebersihan ..

Tabel 10. Distribusi responden berdasarkan tindakan pemeliharaan kebersihan gigi tiruan lepasan

\begin{tabular}{|c|c|c|c|c|}
\hline No & Pertanyaan & $\mathbf{Y a}$ & Tidak & $\begin{array}{l}\text { Total skor } \\
\text { penelitian }\end{array}$ \\
\hline 1. & $\begin{array}{l}\text { Apakah saudara/saudari memperhatikan kebersihan } \\
\text { rongga mulut saat menggunakan gigi tiruan? }\end{array}$ & 15 & 47 & 77 \\
\hline 2. & $\begin{array}{l}\text { Apakah saudara/saudari menjaga kebersihan gigi } \\
\text { tiruan agar tidak menimbulkan gangguan pada } \\
\text { kesehatan gigi dan mulut? }\end{array}$ & 15 & 47 & 77 \\
\hline 3. & $\begin{array}{l}\text { Apakah saudara/saudari membersihkan permukaan } \\
\text { gigi tiruan agar mencegah jamur dan bakteri } \\
\text { berkembang pada permukaan gigi tiruan? }\end{array}$ & 14 & 48 & 76 \\
\hline 4. & $\begin{array}{l}\text { Apakah saudara/saudari membersihkan gigi tiruan } \\
\text { setiap selesai makan? }\end{array}$ & 17 & 45 & 78 \\
\hline 5. & $\begin{array}{l}\text { Apakah saudara/saudari membersihkan gigi tiruan } \\
\text { yang digunakan dengan cara disikat dan } \\
\text { menggunakan sabun/detergen untuk menghilangkan } \\
\text { sisa makanan dan bakteri serta jamur yang } \\
\text { menempel ada permukaan gigi tiruan? }\end{array}$ & 62 & 0 & 124 \\
\hline 6. & $\begin{array}{l}\text { Apakah saudara/saudari merendam gigi tiruan yang } \\
\text { sudah disikat dan dibersihkan menggunakan } \\
\text { sabun/detergen dalam larutan perendam gigi tiruan? }\end{array}$ & 1 & 61 & 63 \\
\hline 7. & $\begin{array}{l}\text { Apakah saudara/saudari melepas gigi tiruan pada } \\
\text { saat akan tidur malam dan direndam dalam air } \\
\text { bersih? }\end{array}$ & 15 & 47 & 77 \\
\hline
\end{tabular}

Saat ini media informasi begitu terbuka luas, namun bila dilihat kondisi sosial ekonomi responden yang masih terbilang kurang (sebagian besar responden berstatus IRT atau tidak bekerja), maka kemungkinan mendapatkan pengetahuan dari media cetak, elektronik ataupun internet sangat kurang. Kondisi yang ada ikut membentuk pengetahuan responden.

Rendahnya tingkat ekonomi responden terlihat dari hasil yang ada yakni sebanyak $88,7 \%$ responden lebih memilih pergi ke tukang gigi untuk menggantikan gigi yang hilang, karna biayanya yang lebih murah. Pembuatan gigi tiruan di tukang gigi biasanya tidak diikuti dengan pemberian informasi tentang pentingnya perawatan kebersihan gigi tiruan karena bisa berdampak pada kesehatan rongga mulut Hal tersebut memengaruhi pengetahuan mereka terhadap pemeliharaan gigi tiruan lepasan. Semakin tinggi penghasilan dan tingkat pendidikan seseorang, maka tingkat pengetahuannya pun akan semakin bertambah, karena adanya kemampuan untuk menyerap informasi semakin tinggi demikian halnya kemudahan untuk mengakses berbagai sumber informasi termasuk tentang kesehatan gigi. ${ }^{12}$

Hasil pada Tabel 8 menunjukkan 53 dari 62 responden tidak mengetahui dampak buruk pemakaian gigi tiruan pada kebersihan gigi dan mulut. Hasil ini menunjukkan bahwa pengetahuan masyarakat tentang dampak buruk pemakaian gigi tiruan pada kebersihan rongga mulut masih kurang. Hal ini sejalan dengan hasil penelitian yang dilakukan oleh Bagaray et al. ${ }^{13}$ pada masyarakat Desa Treman dimana sebagian besar responden tidak mengetahui bahwa pemakaian gigi tiruan dapat berdampak buruk bagi kebersihan rongga mulut.

Hasil selanjutnya memperlihatkan bahwa sebagian besar responden (54 dari 62 responden) tidak tahu bahwa jamur bisa bertumbuh dan berkembang pada permukaan gigi tiruan yang kurang terjaga kebersihannya dan sebagian besar responden juga tidak tahu bahwa gigi tiruan yang kurang terjaga kebersihannya dapat menimbulkan gangguan pada kesehatan gigi dan mulut. Hal ini menyebabkan responden tidak begitu peduli dengan 
pemeliharaan kebersihan gigi tiruan yang digunakannya. Hasil ini sejalan dengan penelitian yang dilakukan oleh Dikbas et al. ${ }^{8}$ yang menyimpulkan bahwa sebagian besar pengguna gigi tiruan tidak menjaga kebersihan gigi tiruannya secara teratur dan memakai gigi tiruannya dalam kondisi yang kotor. Hasil yang ada menunjukkan bahwa mayoritas responden tidak mengetahui akibat-akibat yang dapat terjadi dari pemakaian gigi tiruan yang tidak terjaga kebersihannya, antara lain bertambahnya akumulasi plak meningkatnya frekuensi karies, memburuknya kebersihan mulut, radang gingiva dan goyangnya gigi.

Sebagian besar responden (44 dari 62 responden) tidak tahu tentang pentingnya membersihkan gigi tiruan sehabis makan, juga tidak tahu bahwa gigi tiruan perlu direndam dalam larutan pembersih setelah dibersihkan dengan sikat dan sabun serta perlu dilepas dan direndam dalam air bersih pada malam hari sebelum tidur. Hasil yang ada menggambarkan masih rendahnya pengetahuan responden tentang pemeliharaan kebersihan gigi tiruan. Hal ini sejalan dengan hasil penelitian yang dilakukan oleh Muluwere et al. ${ }^{14}$ menyatakan bahwa sebagian besar responden (22 dari 30 responden) tidak mengetahui pada malam hari gigi tiruan harus dilepas dan direndam dalam air bersih. Pengetahuan masyarakat pengguna gigi tiruan yang masih tergolong kurang baik ini disebabkan oleh kurangnya pemahaman mereka tentang cara pemeliharaan gigi tiruan yang digunakan. Terdapat beberapa responden yang menjawab tahu menyatakan bahwa mereka hanya sekedar mengetahui atau bisa dikatakan pengetahuannya masih sangat superfisial. Mereka belum memahami lebih dalam manfaatnya bila gigi tiruan dipelihara kebersihannya dan juga mengenai dampak dari pemakaian gigi tiruan yang kurang terpelihara kebersihannya.

Sikap merupakan penilaian masyarakat pengguna gigi tiruan dan kesiapan mereka untuk bertindak. Sikap masyarakat terhadap pemeliharaan kebersihan GTL di desa Kema II secara keseluruhan diperoleh skor 581 yang tergolong kurang baik. Kesadaran yang ditunjukkan melalui sikap mereka yang kurang disebabkan oleh kurangnya pengetahuan responden dalam memelihara gigi tiruan. Tidak adanya instruksi tentang pemeliharaan kebersihan yang diterima ketika gigi tiruan selesai dibuat dan minimnya pengetahuan responden berkaitan dengan pemeliharaan gigi tiruan yang mereka pakai membentuk sikap dari responden. Hal ini sejalan dengan penelitian Peranci dimana sebagian besar pemakai gigi tiruan $(51,89 \%)$ tidak tahu bagaimana cara untuk membersihkan gigi tiruan karena tidak adanya intruksi dari dokter gigi yang membuatnya. Pengetahuan sangat diperlukan untuk terbentuknya sikap yang benar dari seseorang. Informasi atau pengetahuan untuk membentuk sikap tidak hanya diperoleh lewat pendidikan formal, namun pengetahuan untuk membentuk sikap bisa diperoleh juga dari berbagai media informasi serta dari berbagai program promosi kesehatan yang dilakukan oleh pemerintah. Salah satu alasan seseorang menunjukkan sikap dalam hal memperoleh kesehatan adalah suatu inovasi yang dapat memotivasi responden. ${ }^{15-17}$ Melalui inovasi atau program-program kesehatan serta sosialisasi dan instruksi dalam memelihara gigi tiruan, responden bisa mengadopsi nilai-nilai yang baik berkaitan dengan upaya pemeliharaan kesehatan gigi dan mulut, sehingga responden bisa mendapatkan pengetahuan dan sikap yang baik.

Sikap responden tergolong kurang ditunjukkan oleh 43 dari 62 responden yang tidak setuju bahwa pemakaian gigi tiruan dapat berdampak buruk di rongga mulut jika gigi tiruan kurang terjaga kebersihannya. Selanjutnya sebagian besar responden tidak setuju bahwa gigi tiruan yang kurang terjaga kebersihannya dapat menimbulkan gangguan pada kesehatan gigi dan mulut. Sikap yang sama juga ditunjukkan oleh sebagian besar responden yang tidak setuju bahwa gigi tiruan yang kurang terjaga kebersihannya, menyebabkan jamur dan bakteri bisa tumbuh dan berkembang. Hal tersebut menunjukkan bahwa responden tidak mengetahui bahwa 
ada dampak dari pemakaian gigi tiruan yang tidak dijaga kebersihannya.

Sikap responden yang kurang baik terhadap pemeliharaan gigi tiruan ditunjukkan dari hasil penelitian yang sebagian besar responden tidak setuju bahwa gigi tiruan harus dibersihkan setiap selesai makan. Kurang pahamnya responden akan dampak gigi tiruan kurang bersih bagi kesehatan rongga mulut, menyebabkan munculnya sikap seperti itu. Bila mereka paham, tentunya mereka akan memiliki sikap yang berbeda. Dalam pemeliharaan gigi tiruan yang digunakan, semua responden setuju bahwa gigi tiruan yang digunakan harus disikat menggunakan sabun/detergen setiap selesai makan untuk menghilangkan sisa makanan dan bakteri serta jamur yang menempel pada permukaannya. Hal tersebut bisa memberikan hasil yang baik karena pengetahuan yang dimiliki masih dangkal. Umumnya hampir setiap orang memahami bahwa gigi harus dijaga kebersihannya termasuk gigi tiruan yang digunakan, namun dampak gigi tiruan yang kurang bersih bagi kesehatan rongga mulut mungkin belum dipahami oleh sebagian besar responden yang memengaruhi sikap responden. Pengetahuan yang baik akan berdampak pada pembentukan sikap yang baik dan benar.

Hal sebaliknya ditunjukkan responden bahwa sebagian besar responden tidak setuju jika gigi tiruan harus direndam dalam larutan pembersih gigi tiruan; demikian halnya dengan pernyataan bahwa gigi tiruan harus dilepas pada malam hari dan direndam dalam air bersih. Responden memiliki sikap demikian karena didasari pengetahuan yang masih kurang. Hasil yang sama juga diperoleh dari penelitian Titjo et al. ${ }^{2}$ dimana sebagian besar responden tidak setuju bahwa gigi tiruan harus dilepas pada malam hari dan direndam dalam air bersih. Hal ini disebabkan karena masih kurangnya pemahaman akan dampaknya jika perendaman tidak dilakukan, yakni dapat mengakibatkan gigi tiruan tersebut mengerut sehingga akan menyebabkan gigi tiruan tidak pas pada mulut pengguna. Demikian halnya dengan gigi tiruan yang tidak dilepas dan dipakai secara terus menerus dan tidak dibersihkan, dapat menyebabkan peningkatan jumlah pertumbuhan bakteri Candida albicans.

Tindakan merupakan wujud dari pengetahuan dan sikap masyarakat pengguna gigi tiruan. Tindakan masyarakat terhadap pemeliharaan kebersihan gigi tiruan lepasan di Desa Kema II memperoleh skor 572 yang masih tergolong pada kategori kurang baik. Keadaan ini sesuai dengan pengetahuan dan sikap responden yang masih kurang baik pula. Tindakan yang tergolong kurang ini didasarkan pada pengetahuan responden yang juga masih kurang. Hal ini disebabkan karena masih kurangnya kesadaran pengguna gigi tiruan dalam memelihara gigi tiruan yang dipakai. Selain itu, kurangnya tindakan masyarakat pengguna gigi tiruan ini dilandasi oleh faktor ekonomi dan faktor pendidikan. Seseorang dengan tingkat pendidikan yang tinggi akan lebih mengerti cara pemeliharaan kesehatan, termasuk kesehatan rongga mulut bagi pengguna gigi tiruan, demikian halnya dengan keadaan ekonomi. Keadaan ekonomi yang tinggi juga menunjang seseorang untuk mendapat pelayanan kesehatan yang memadai. Perawatan pembuatan gigi tiruan yang dilakukan di dokter gigi akan memungkinkan responden memperoleh informasi atau pengetahuan yang cukup dalam pemeliharaan gigi tiruannya. Pada penelitian ini sebagian responden membuatkan gigi tiruannya di tukang gigi, sehingga informasi yang dibutuhkan untuk pemeliharaan gigi tiruan kurang didapatkan. Hal ini tergambar dari hasil yang ada, dimana sebagian besar responden kurang memerhatikan, menjaga dan memelihara kebersihan gigi tiruan yang digunakan. Kurangnya tindakan responden dalam pemeliharaan kebersihan gigi tiruannya ditunjukkan dengan kondisi rongga mulut responden. Saat melakukan penelitian, terlihat umumnya permukaan gigi tiruan telah mengalami perubahan warna, berbau, dan tidak bersih. Hal ini 
disebabkan karena sebagian besar responden tidak membersihkan gigi tiruan setiap selesai makan sehingga dapat menyebabkan bakteri dan jamur berkembang di permukaan gigi tiruan.

Dalam pemeliharaan gigi tiruan, tindakan yang baik ditunjukkan oleh semua responden yang membersihkan gigi tiruan dengan menggunakan sabun/detergen untuk menghilangkan sisa makan dan bakteri serta jamur yang menempel pada permukaan gigi tiruan. Hasil yang sama ditunjukkan pada penelitian Mapanawang ${ }^{18}$ dimana sebagian besar responden membersihkan gigi tiruan dengan menggunakan sabun/deterjen. ${ }^{18}$ Hasil ini menggambarkan bahwa responden sudah mengerti cara membersihkan gigi tiruan, namun belum memahami alasan mengapa tindakan tersebut harus dilakukan dan dampaknya bila tidak dilakukan. Responden juga sebagian besar tidak melepas gigi tiruan mereka pada malam hari. Hasil yang sama juga diperoleh dari penelitian yang dilakukan oleh Lengkong ${ }^{19}$ dimana 22 dari 30 responden tidak melepas gigi tiruan pada malam hari. Demikian halnya dengan merendam gigi tiruan dalam larutan pembersih gigi tiruan saat dilepas dan tidak digunakan. Hanya 1 dari 62 reponden saja yang merendam dalam larutan pembersih gigi tiruan saat gigi tiruan selesai disikat, sedangkan yang lain tidak pernah merendam gigi tiruan dalam larutan pembersih karena kurangnya pengetahuan dan mungkin juga karena tidak adanya biaya untuk membeli larutan pembersih gigi tiruan.

\section{SIMPULAN}

Dari hasil penelitian tentang perilaku pemeliharaan kebersihan gigi tiruan lepasan pada masyarakat Desa Kema II Kecamatan Kema, yang terdiri dari pengetahuan, sikap, dan tindakan, dapat disimpulkan bahwa:

1. Pengetahuan pemeliharaan kebersihan gigi tiruan lepasan pada masyarakat tergolong kurang baik.

2. Sikap pemeliharaan kebersihan gigi tiruan lepasan pada masyarakat tergolong kurang baik.

3. Tindakan pemeliharaan kebersihan gigi tiruan lepasan pada masyarakat tergolong kurang baik.

\section{SARAN}

1. Bagi pemerintah dalam hal ini puskesmas setempat disarankan untuk dapat melakukan upaya preventif dan promotif di bidang kesehatan gigi dan mulut melalui penyuluhan bagi pengguna gigi tiruan lepasan guna meningkatkan perilaku pemeliharaan kebersihan gigi tiruan lepasan.

2. Bagi masyarakat disarankan agar melakukan perawatan pembuatan gigi tiruan di dokter gigi agar mendapatkan informasi tentang cara pemeliharaan kebersihan gigi tiruan lepasan, sehingga dapat mempertahankan kesehatan jaringan mulut pengguna gigi tiruan penuh serta kesehatan jaringan mulut dan gigi asli yang masih tinggal pada pengguna gigi tiruan sebagian lepasan.

\section{DAFTAR PUSTAKA}

1. Haryanto AG, Margo A, Burhan LK, Suryatenggara F, Setiabudi I. Buku Ajar Gigi Geligi Tiruan Sebagian Lepasan Jilid 1. Jakarta: Hipokrates, 2012; p. 4-15, 33-1.

2. Titjo OC, Lampus BS, Juliatri. Perilaku masyarakat pengguna gigi tiruan lepasan di Kelurahan Bahu. eG. 2013;1(2):1-8.

3. Jubhari EH. Tingkat pemahaman terhadap instruksi cara pembersihan gigi tiruan lepasan pada pasien Rumah Sakit Mulut Fakultas Kedokteran Gigi Universitas Hasanuddin. Jurnal PDGI. 2014;63(2):54-7.

\section{Zarb GA, Bolender CL, Hickey JC, Carlson} GE. Buku Ajar Prostondonti untuk Pasien Tak Bergigi menurut Boucher (10th ed). Mardjono D, alih bahasa. Jakarta: EGC, 2002; p. 2.

5. Agniti MD. Persentase pengguna gigi tiruan di Indonesia. Media Litbang Kesehatan. 2010;XX(2).

6. Rahmayani L. Perilaku pemakaian gigi tiruan terhadap pemeliharaan kebersian gigi tiruan lepasan. Jurnal PDGI. 
2013;62(3):83-8.

7. Basker RM, Davenport JC, Tomlin HR. Perawatan Prostodontik bagi Pasien Tak Bergigi (3rd ed). Soebekti TS, Arsil H, alih Bahasa. Jakarta: EGC, 1996; p. 1-2, 216-8.

8. Dikbas I, Koksal T, Bal B, Ozkurt Z, Kazaoglu E. A survey of dentists' attitudes toward denture cleansing. Turki 2005. OHDMBSC 2006;5(4): 711.

9. Herijulianti E, Indriani TS, Artini S. Pendidikan Kesehatan Gigi. Jakarta: EGC, 2002: p. 24-9.

10. Barreiro DM, Scheid PA, May LG, Unfer B, Braun KO. Evaluation of procedures employed for the maintenance of removable dentures in elderly individuals. Oral Health Prev Dent. 2009;7:243-9.

11. Ozkan Y, Ozcan M, Kulak Y, Kazasoglu E, Arikan A. General health, dental status and perceived dental treatment needs of an elderly population in Istanbul. Gerodontology. 2011;28:2836.

12. Amjad M, Azad AA. Denture hygiene habits in complete denture wearers at Armed Forces Institute of Dentistry. Pakistan Armed Forces Med J. 2005; 4.

13. Bagaray DA, Mariati NW, Leman MA.
Perilaku memelihara kebersihan gigi tiruan lepasan berbasis akrilik pada masyarakat Desa Treman Kecamatan Kauditan. eG. 2014;2(2):

14. Muluwere VO, Mariati NW, Wicaksono DA. Gambaran pengetahuan dan status kebersihan mulut pada pemakai gigitiruan sebagian lepasan di kelurahan Batu Kota kecamatan Malalayang. eG. 2015;3(1):197-202.

15. Notoatmodjo S. Promosi kesehatan teori dan aplikasi. Jakarta: Rineka Cipta, 2010; p. 49-5, 139-41.

16. Peranci A. Behaviour and hyiene habits of complete denture wearers. Braz Dent J. 2010;21:247-52.

17. Pariani N. Konsep tingakat pengetahuan. [serial online] 2010. Available from: URL: http://id.shvoong.com/humanities/lingu istics/2053284-konsep-tingkatpengetahuan/.

18. Mapanawang BN. Gambaran pemeliharaan kebersihan GTL akrilik pada masyarakat Batu Putih bawah. eG. 2014;2(3).

19. Lengkong PEO. Gambaran perilaku dan cara merawat gigi tiruan sebagian lepasan pada lansia di panti werda Minahasa Induk. eG. 2015;3(1):44-50. 